\title{
Productivity Change in the Turkish Banking Industry
}

\section{Hüseyin Daştan}

Erzurum Technical University, Faculty of Economics and Administrative Sciences

huseyin.dastan@erzurum.edu.tr

\section{Gürkan Çalmaşur}

Erzurum Technical University, Faculty of Economics and Administrative Sciences gurkan.calmasur@erzurum.edu.tr

\section{Doi:10.5901/mjss.2015.v6n5p148}

\begin{abstract}
The objective of this study is to make a detailed analysis of the total factor productivity of the banks operating in the Turkish banking industry from 2003 to 2014. We used the panel data of 42 banks and applied the Malmquist Total Factor Productivity Index method separately for each year. We then calculated the pure efficiency change, scale efficiency change, technical efficiency change, technological change and total factor productivity change indices. We found that between 2003 and 2014 , there was a $5.2 \%$ increase in the total factor productivity of banks on average, and this increase was the result of a $2.5 \%$ increase in technical efficiency change index and a $2.7 \%$ increase in the technological change index.
\end{abstract}

Keywords: Turkish Banking Industry, Malmquist Total Factor Productivity Index, Productivity, Data Enveloping Analysis

\section{Introduction}

Globalization means that large international corporations operate in almost every country in the world. This increases the intensity of competition in industry. International banks are active in different countries is a good example of this situation. As of 2014, there are 51 banks operating in the Turkish banking system. Of them, 34 are deposit banks, 13 are development and investment banks, and 4 are participation banks. At present, banks in Turkey have 11,223 branches, and 200,886 personnel are employed by these banks (www.tbb.org.tr).

The effective and productive operation of the banking system is of particular importance from the perspective of the economy. This stems from the fact that, being different from other sectors in the economy, the banking sector assumes the function of a financial intermediary that determines allocation of resources. From this perspective, the banking system takes a central role in the development of nations. It is impossible to talk about effectiveness or productivity of a banking system that cannot turn savings into investments. Therefore, conducting a performance analysis of banking system (analyzing its effectiveness and productivity) is of the utmost importance (Ekren and Emiral, 2002: 1).

One of the important criteria that is used in measuring the performance of a firm or industry is the change in total factor productivity. When it comes to productivity, one should consider the total factor productivity that consists of all the production factors in the production process. Other traditional criteria of productivity are the ones that are known as partial productivity criteria such as labor productivity and land productivity. When partial productivity measures are used separately they can give inaccurate information about the total factor productivity. Dealing with total factor productivity and trying to measure the change in total factor productivity gives more consistent results since change in total factor productivity is twofold and encompasses technical efficiency and technological change (Deliktas, 2002: 248).

The literature contains very different approaches to defining and measuring total factor productivity. These approaches are differentiated by the level at which productivity is measured by the objective of the measurement and by definitions of inputs and outputs. They are also differentiated by the databases available (Buyükkilic and Yavuz, 2005: 17). The most widely used methods for measuring the changes in total factor productivities are Stochastic Production Frontier Analysis and Data Envelopment Analysis (DEA). Both approaches are based on the assumption that some firms do not use their resources effectively, and some firms operate on the production frontier defined by the "best use" of technology. The stochastic frontier approach uses econometric methods, whereas a non-parametric approach, DEA, uses mathematical (linear) programming methods. Both methods use the Malmquist productivity index (Deliktas, 2002: 248-249). Banking sector plays an important role on global financial crises all over the world. The Turkish banking sector 
has significantly changed especially after the 2001 economic crisis. The efficiency of the Turkish banking sector has also directly an important impact on the Turkish economy. In this respect, the efficiency analysis of the Turkish banking sector may provide a valuable information for the future position of the corresponding sector.

DEA is one of the non-parametric efficiency measurements methods developed to measure the relative efficiencies of economic units that are similar to each other with respect to products and services they produce (Boussofiane and Rhodes, 1991). DEA, which was initially used to compare the efficiencies of nonprofit public enterprises, later began to be used widely to measure the technical efficiency differences of for-profit manufacturing and services sector firms.

This study measures total factor productivity and its constituents, technical efficiency and technological change, using the Malmquist Total Factor Productivity Index. Its fundamental objective is to analyze the total factor productivity of the Turkish banking industry between 2003 and 2014. Within this context, total factor productivities and technical efficiency change as well as technological change, which are the sources of them, of the firms operating in the Turkish banking industry have been brought to the fore and the factors that cause to unproductivity have also been determined.

This study has six sections. The second section is a literature review. The third section deals with methodology. The fourth section evaluates the data and variable definitions, and the fifth section summarizes and interprets the estimation results. The final section draws conclusions from the results.

\section{Literature Review}

Many Turkish and foreign studies measure the total factor productivity of banking systems. Here, we summarize some of this research. Fukuyama (1995) studied the productivity of the Japanese banking industry between 1989 and 1991. Tatje and Lovell (1996) explored total factor productivity between 1986 and 1991 in Spain. Alam (2001) investigated the total factor productivity of the US banking industry. Drake (2001) examined the productivity of British banking sector between 1984 and 1995. Sathye (2002) examined the productivity of 17 banks in Austria's banking system between 1995 and 1995. Vivas and Humphrey (2002) analyzed Spanish banking productivity between 1986 and 2001. Asmild et al. (2004) worked on the productivity of Canadian banking industry between 1981 and 2000. Casu et al. (2004) compared the productivity of the banking industries in Germany, France, the UK, Spain, and Italy between 1993 and 1997. Galagedera and Edirisuriya (2004) analyzed the productivity of India's banking sector between 1995 and 2002. Sturm and Williams (2004) studied Australian banking industry performance between 1988 and 2001. Kirikal et al. (2004) examined the performance of the banking industry in Estonia between 1994 and 2002. Primorac and Troskot (2005) studied the performance of Croatia's banking sector between 2000 and 2003. Lyroudi and Angelidis (2006) studied the productivities of the banking sectors of EU-member countries between 1996 and 2002. Sufian (2007) explored the total factor productivity of Malaysia's Islamic banking industry between 2001 and 2004. Hadad et al. (2008) examined the productivity of 130 banks in Indonesia between 2006 and 2007. Reda (2008) evaluated the performance of Egypt's banking industry between 1995 and 2003. Sharma and Gupta (2010) looked at productivity of India's banking industry between 1996 and 2006. Arjomandi et al. studied (2011) analyzed Iran's banking industry performance between 2002 and 2008. Neupane (2013) assessed the productivity of the banking industry in Nepal between 2001 and 2012. Rahman and Rosman (2013) worked on productivity of the banking sector in the Middle East and North Africa between 2006 and 2009. Raphael (2013) studied the productivity of the Tanzanian banking industry between 2005 and 2011. Muvingi and Hotera (2015) analyzed productivity of the banking industry in Africa between 2002 and 2012.

There are numerous studies that use the Malmquist total factor productivity index to examine Turkey's banking sector in different years. Jackson et al. (1998) studied the total factor productivity of Turkish commercial banks between 1992 and 1996. Cingi and Tarim (2000) examined the Turkish banking industry's performance between 1989 and 1996. Isik and Hassan (2003) and Karacabey and Aslan (2004) studied productivity levels from 1992 to 1996 and from 1997 to 2000 , respectively. Bastı (2005) examined the effect of the 2001 financial crisis on productivity. Turker, Kaya and Dogan (2005) investigated productivity change between 2002 and 2004. Chambers and Atilla (2006) explored effectiveness and productivity between 2002 and 2004. Percin and Ayan (2006) worked on economic performance between 2003 and 2004. Aysan and Ceyhan (2007) analyzed the change between 1990 and 2006. Oncu and Aktas (2007) looked at productivity between 2001 and 2005. Bozdag et al. (2010) evaluated the productivity of 32 commercial banks between 2006 and 2009. Eken and Kale (2011) analyzed efficiency and productivity in the sector. Kasman and Kasman (2011) investigated efficiency and productivity between 1998 and 2008. Unvan and Tatlidil (2012) analyzed the productivities of banks operating in Turkish banking sector between 2002 and 2008, and Akyuz et al. (2013) repeated the same research for the years between 2007 and 2011. Similar research has been conducted by Benli and Degirmen (2013) for 2004 to 2009, Kok and Ay (2013) for 2007 to 2009, Ada and Dalkilic for 2009 to 2011, Boyacioglu et al. (2014) for 2011 to 2013, Coban et al. (2015) for 1995 to 2010, Dizkirici and Gokgoz (2015) for 2010 to 2013 and Kutlar et al. (2015) for 2003 to 2012. 


\section{Methodology}

In this section, we analyze the Malmquist Total Factor Productivity Index method that we used to calculate productivity of banks that are actively operating in Turkish banking sector.

One of the methods commonly used to estimate the distance functions required for the calculation of the Malmquist total factor productivity index is the data envelopment analysis. DEA is a non-parametric method, which benefits from mathematical linear programming problem.DEA is a methodology, that aims to construction of best production frontier or substitute the regression space that will best fit the data center with a linear partial surface that will contain extreme values, without imposing any restrictions on the production technology (Arnade, 1994: 8).

The first company-specific Malmquist productivity index was developed by Caves et al. in 1982. The index is named after Steven Malmquist, who defined the input amount indices as the ratio of distance functions. The Malmquist indices are made up of distance function ratios that are used to model the production frontier. Caves et al. defined the Malmquist index as a theoretical index and showed that under certain conditions the Törnqvist index could be derived from this theoretical index. To define the Malmquist productivity index it is assumed that in the time interval $t=1, \ldots, \mathrm{T}$, conversion of $x^{t} \in \Re_{+}^{N}$ inputs into $y^{t} \in \Re_{+}^{M}$ outputs shapes the production technology $S^{t}$. Based on Shephard (1970) and Fare et al. (1988), the output distance function at time t is defined as below (Grosskopf, 1993: 175):

$$
D_{0}^{t}\left(x^{t}, y^{t}\right)=\min \left\{\theta:\left(x^{t}, y^{t} / \theta\right) \in S^{t}\right\}
$$

The value that the distance function $D_{0}^{t}\left(x^{t}, y^{t}\right)$ takes is equal to one if the vector $y^{t}$ is on (production frontier) $S^{t}$. It is greater than 1 if the vector $y^{t}$ defines a technical non-efficient point in $S^{t}$, and it is less than 1 if the vector $y^{t}$ defines an impossible point outside of $S^{t}$ (Cingi and Tarim, 2000: 10).

To define the Malmquist productivity index it is necessary to define two different distance functions for the periods $t$ and t+1 (Grosskopf, 1993: 175-176).

$$
\begin{aligned}
& D_{0}^{t}\left(x^{t+1}, y^{t+1}\right)=\min \left\{\theta:\left(x^{t+1}, y^{t+1} / \theta\right) \in S^{t}\right\} \\
& D_{0}^{t+1}\left(x^{t}, y^{t}\right)=\min \left\{\theta:\left(x^{t}, y^{t} / \theta\right) \in S^{t+1}\right\}
\end{aligned}
$$

Distance function number 2 measures the maximum proportional change in the output to realize $\left(x^{t+1}, y^{t+1}\right)$ in the technology in period $t$, whereas distance function number 3 measures the maximum proportional change in the output to realize $\left(x^{t}, y^{t}\right)$ in the technology in period $t+1$. he Malmquist productivity indices for the $t$ and $t+1$ technology levels are presented below:

$$
M_{0}^{t}=\frac{D_{0}^{t}\left(x^{t+1}, y^{t+1}\right)}{D_{0}^{t}\left(x^{t}, y^{t}\right)}
$$

Equation number 4 measures the productivity changes between the $t$ base period and $t+1$ current period with respect to $t$ technology level, while equation number 5 measures the productivity changes between $t+1$ base period and $t$ current period with respect to the t+1 technology level. The reference technology in equation number is $S^{t}$, whereas it is $S^{t+1}$ in equation number 5 (Buyukkilic and Yavuz, 2005: 44).

$$
M_{0}^{t+1}=\frac{D_{0}^{t+1}\left(x^{t+1}, y^{t+1}\right)}{D_{0}^{t+1}\left(x^{t}, y^{t}\right)}
$$

Fare et al. (1989) took the geometric average of indices given in number 4 and number 5 and obtained this output oriented Malmquist index (Grosskopf, 1993: 177):

$$
M_{0}\left(x^{t+1}, y^{t+1}, x^{t}, y^{t}\right)=\frac{D_{0}^{t+1}\left(x^{t+1}, y^{t+1}\right)}{D_{0}^{t}\left(x^{t}, y^{t}\right)}\left[\frac{D_{0}^{t}\left(x^{t+1}, y^{t+1}\right)}{D_{0}^{t+1}\left(x^{t+1}, y^{t+1}\right)} \frac{D_{0}^{t}\left(x^{t}, y^{t}\right)}{D_{0}^{t+1}\left(x^{t}, y^{t}\right)}\right]^{1 / 2}
$$

An $M_{0}$ index of 1 shows that total factor productivity increased from period t to period $t+1$. Conversely, when this value is less than 1, it indicates that total factor productivity decreases from period t to period $t+1$ (Coelli, 1996: 28).

Dividing the Malmquist total factor productivity into technical efficiency change and technological change helps to determine the contribution of each factor to the total factor productivity. When the equation is divided into two sections, it is possible to measure the change in efficiency and the change in technology separately.

$$
\text { Technical Change }=\frac{D_{0}^{t+1}\left(x^{t+1}, y^{t+1}\right)}{D_{0}^{t}\left(x^{t}, y^{t}\right)}
$$


Technological Change $=\left[\frac{D_{0}^{t}\left(x^{t+1}, y^{t+1}\right)}{D_{0}^{t+1}\left(x^{t+1}, y^{t+1}\right)} \frac{D_{0}^{t}\left(x^{t}, y^{t}\right)}{D_{0}^{t+1}\left(x^{t}, y^{t}\right)}\right]^{1 / 2}$

The change in technical efficiency is seen as a catching-up effect on the production frontier, while technological change is assessed as the frontier effect (a shift in production possibilities line) (Mahadevan, 2002: 590). The multiplication of technical efficiency change (TEC) by technological change (TC) yields the Malmquist total factor productivity index (Kok and Simsek, 2006: 5). In order to calculate the productivity of any country $\mathrm{k}^{\prime}$ in the periods $\mathrm{t}$ and $\mathrm{t}+1$, four distance functions $\left(D_{0}^{t}\left(x^{t}, y^{t}\right), D_{0}^{t+1}\left(x^{t+1}, y^{t+1}\right), D_{0}^{t}\left(x^{t+1}, y^{t+1}\right), D_{0}^{t+1}\left(x^{t}, y^{t}\right)\right.$ ) should be calculated, and this requires solving four linear programming problems. The LPs that will be needed under the assumption of constant returns with respect to scale are the followings (Fare et al., 1994: 75):

The four LP problems below should be solved for each of the decision-making types in the example. Therefore, if there are 20 decision-making units and two periods, then $80 \mathrm{LP}$ problems should be solved. Thus, in the presence of $T$ time periods and I decision making units, the number of LP problems that should be solved is IX(4T-2) (Coelli et al., 2005: 295)

The number of linear programming that should be solved in our study is $L P=42 \times(4.12-2)=1932$. The four systems below require that 1932 linear programming models be solved. These solutions help us determine the productivity level of each bank and sources of changes in these productivity levels.

I.

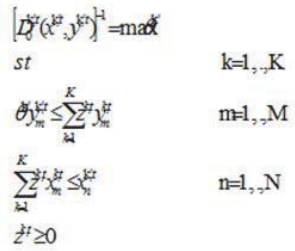

III.

$$
\begin{aligned}
& {\left[D_{0}^{K, t}\left(x^{K, t+1}, y^{K, t-1}\right)\right]^{-1}=\max \theta^{K}} \\
& s t \\
& \theta^{K} y_{m}^{K, t-1} \leq \sum_{k=1}^{K} z^{k, t} y_{m}^{k, t} \\
& \sum_{k=1}^{K} z^{k t} x_{m}^{k, t} \leq x_{n}^{K, t+1} \\
& z^{k, t} \geq 0
\end{aligned}
$$

II.

$$
\begin{aligned}
& {\left[D_{0}^{K t+1}\left(x^{K t+1}, y^{K t+1}\right)\right]^{-1}=\max \theta^{K}} \\
& \text { st } \\
& \theta^{K} y_{m}^{k t+1} \leq \sum_{k=1}^{K} z^{k+1} y_{m}^{k t+1} \\
& \sum_{k=1}^{K} z^{k, k+1} x_{m}^{k, k+1} \leq x_{n}^{k, k+1} \\
& z^{k, s+1} \geq 0
\end{aligned}
$$

Iv.

$$
\begin{aligned}
& {\left[D_{0}^{K, t+1}\left(x^{K, t}, y^{K, t}\right)\right]^{-1}=\max \theta^{K}} \\
& s t \\
& \theta^{K} y_{m}^{K, t} \leq \sum_{k=1}^{K} z^{k, t} y_{m}^{k, t+1} \\
& \sum_{k=1}^{K} z^{k, t} x_{m}^{k, t-1} \leq x_{n}^{K, t} \\
& z^{k, t} \geq 0
\end{aligned}
$$

If the technical efficiency index has a value greater than 1 , it indicates that the decision-making units are able to adapt to global technologies and internalize them. The technical efficiency change index can be separated into the two components of pure efficiency change and scale efficiency change. This means that TEC=PEC $x$ SEC. The first index means better use of existing production factors, while the second shows whether the decision-making units produce at the optimal scale or not. Both index values being greater than 1 indicates improvement, and both being less than 1 indicates decline. The technological change index expresses the change in the best production frontier. When this index is greater than 1 this shows an upward shift in the production frontier. The total factor productivity change index does change with respect to these two indices. This means that TFPC=TEC x TC (Deliktas, 2006: 17).

A total factor productivity change index greater than 1 indicates an increase in the total factor productivity, and this index being less than 1 indicates a decrease in the total factor productivity. Technical efficiency change can be divided into pure efficiency change and scale efficiency change. Scale efficiency change indicates decision-making units' success at producing at the appropriate scale (Deliktas, 2002: 263).

Due to the difficulty of calculating distance functions under the assumption of returns that are changing with respect to scale, the Malmquist TFP index may not accurately measure the changes in total factor productivity all the time. Hence, the indices obtained might not reflect total factor productivity gains and losses arising from scale efficiency in an appropriate way. Therefore, in order to estimate the distance functions used in calculating the Malmquist total factor productivity index, it is assumed that technology registers constant returns with respect to scale (Coelli et al., 2005: 224). 
For this reason, when making a comparison between economic performances of banks, we preferred technical efficiency and total factor productivity indices that were obtained under the assumption of constant returns with respect to scale.

In this study, the Malmquist Total Factor Productivity Index method was constructed for each of the years separately, and technical efficiency change, technological change and total factor productivity change indices were calculated with the DEAP 2.1 software that was developed by Coelli (1996).

\section{Data and Variables}

The inputs and outputs used in productivity analyses define the results. In order to decide on the inputs and outputs that would be used in this research, we analyzed the inputs and outputs used in the other studies in the literature. The input and output variables of this study were taken from the statistical reports, entitled Our Banks, which are published every year by the Banks Association of Turkey (www.tbb.org.tr).

The data set includes the banks that were active in all the years from 2003 to 2014 . The banks that were used as the data set in the study and other banks included in the implementation section of this study and their codes are presented in Table 1. Republic of Turkey Ziraat Bank Inc., Turkish Halk Bank Inc., and Turkish Vakiflar Bank Corporation are public-capital banks. Adabank Inc., Akbank Inc., Anadolubank Inc., Fibabanka Inc., Şekerbank Inc., Tekstil Bank Inc., Turkish Bank Inc., Turkish Economy Bank Inc., Turkish Garanti Bank Inc., Turkish Is Bank Inc., and Yapı Kredi Bank Inc. are private-capital banks. Joint Funds Bank Inc is a bank that was transferred to the Savings Deposit Insurance Fund of Turkey, Alternatifbank Inc., Arab Turkish Bank Inc., Bank Mellat, Burgan Bank Inc., Citibank Inc., Denizbank Inc., Deutsche Bank Inc., Finans Bank Inc., Habib Bank Limited, HSBC Bank Inc., ING Bank Inc., JPMorgan Chase Bank N. A., Société Générale (SA), The Royal Bank of Scotland PIc and Turkland Bank are foreign-capital banks. Aktif Investment Bank Inc., BankPozitif Credit and Development Bank Inc., Diler Investment Bankasi, GSD Investment Bank Inc., Ilbank Inc., Istanbul Settlement and Custody Bank Inc., Merrill Lynch Investment Bank Inc., Nurol Investment Bank Inc., Standart Chartered Investment Bank Turk Inc., Turk Eximbank, the Development Bank of Turkey Inc. and the Industrial Development Bank of Turkey Inc. are development and investment banks.

Table 1. Banks and Codes

\begin{tabular}{|c|l|c|l|c|l|}
\hline Code & Banks & Code & Banks & Code & Banks \\
\hline B-1 & Adabank & B-15 & Fibabank & B-29 & Tekstil Bank \\
\hline B-2 & Akbank & B-16 & Finans Bank & B-30 & The Royal Bank of Sc \\
\hline B-3 & Aktif Yatıım Bank & B-17 & GSD Yatırım & B-31 & Turkish Bank \\
\hline B-4 & Alternatifbank & B-18 & Habib Bank Limited & B-32 & Turkland Bank \\
\hline B-5 & Anadolubank & B-19 & HSBC Bank & B-33 & Türk Ekonomi Bank \\
\hline B-6 & Arap Türk Bank & B-20 & ING Bank & B-34 & Türk Eximbank \\
\hline B-7 & Bank Mellat & B-21 & İller Bankası & B-35 & Ziraat Bank \\
\hline B-8 & Bank Pozitif & B-22 & İstanbul Takas ve Saklama & B-36 & Garanti Bank \\
\hline B-9 & Birleşik Fon Bank & B-23 & JPMorgan Chase Bank & B-37 & Halk Bank \\
\hline B-10 & Burgan Bank & B-24 & Merrill Lynch Bank & B-38 & İş Bank \\
\hline B-11 & Citibank & B-25 & Nurol Yatırım Bank & B-39 & Kalkınma Bank \\
\hline B-12 & Denizbank & B-26 & Société Générale (SA) & B-40 & Sınai Kalkınma Bank \\
\hline B-13 & Deutsche Bank & B-27 & Standard Chartered & B-41 & Vakıflar Bank \\
\hline B-14 & Diler Yatırım Bank & B-28 & Şekerbank & B-42 & Yapı ve Kredi Bank \\
\hline
\end{tabular}

Including newly opened and closed banks, total of 55 banks were active between 2003 and 2014. Of these banks, 42 banks were active throughout this period and were therefore included in these analyses. The banks are in alphabetical order, and each bank was assigned a code in the table below. The data set of our study consists of 504 observations obtained in 12 years for the 42 banks. Benefitting from the other studies in the literature, we used total loans and total deposits as the output variables and total assets, number of branches and number of employees as the input variables.

\section{Empirical Findings}

In this section we use the Malmquist Total Factor Productivity Index method to calculate technical efficiency change, technological change and total factor productivity change indices for the Turkish banks that were active in all the years from 2003 to 2014 in Turkey. In addition, we deal with sources of total factor productivity and technical efficiency change 
in detail. In the tables analyzing the total factor productivity we used geometric averages as the average value.

In order to convert the figures into percentages in the tables where the Malmquist total factor productivity index results are presented, 1 should be deducted from each number in the table and the results should be multiplied by 100 . Table 2 shows the total factor productivity changes and sources of this change for the period between 2003 and 2014.

Table 2. Changes in All Banks' Total Factor Productivity and Its Components by Period (Malmquist Index Summary of Annual Means)

\begin{tabular}{|c|c|c|c|c|c|}
\hline Periods & $\begin{array}{c}\text { Technical } \\
\text { Efficiency Change }\end{array}$ & $\begin{array}{c}\text { Technological } \\
\text { Change }\end{array}$ & $\begin{array}{c}\text { Pure Technical Efficiency } \\
\text { Change }\end{array}$ & $\begin{array}{c}\text { Scale Efficiency } \\
\text { Change }\end{array}$ & $\begin{array}{c}\text { Total Factor Productivity } \\
\text { Change }\end{array}$ \\
\hline $2003-2004$ & 1.142 & 1.007 & 1.026 & 1.113 & 1.149 \\
\hline $2004-2005$ & 1.043 & 1.034 & 1.026 & 1.016 & 1.078 \\
\hline $2005-2006$ & 1.111 & 0.931 & 1.035 & 1.073 & 1.034 \\
\hline $2006-2007$ & 1.131 & 0.877 & 1.191 & 0.940 & 0.992 \\
\hline $2007-2008$ & 0.928 & 1.292 & 0.973 & 0.954 & 1.199 \\
\hline $2008-2009$ & 0.929 & 1.111 & 0.968 & 0.959 & 1.032 \\
\hline $2009-2010$ & 1.087 & 0.988 & 1.018 & 1.068 & 1.074 \\
\hline $2010-2011$ & 0.920 & 1.081 & 0.958 & 0.960 & 0.994 \\
\hline $2011-2012$ & 1.027 & 1.005 & 0.993 & 1.034 & 1.032 \\
\hline $2012-2013$ & 0.987 & 1.026 & 0.976 & 1.012 & 1.013 \\
\hline $2013-2014$ & 1.001 & 0.992 & 0.976 & 1.025 & 0.993 \\
\hline MEAN & 1.025 & 1.027 & 1.011 & 1.014 & 1.052 \\
\hline
\end{tabular}

Table 2 shows that from 2003 to 2014, there was an average of $5.2 \%$ increase in the total factor productivities of the banks. The two sources of this increase are a 2.5\% average increase in the technical efficiency change index and a $2.7 \%$ increase in the technological change index. In the same period, sources of the $2.5 \%$ positive technical efficiency change are an annual average of $1.1 \%$ positive pure efficiency change and an annual average of $1.4 \%$ positive scale efficiency change. In other words, banks managed their current production factors well and operated at the optimal production scale. Except for 2006-2007, 2010-2011 and 2013-2014, in all other years there was an increase in total factor productivity.

For all the banks, the biggest total factor productivity increase was registered in 2003 and 2004 with the annual average of $14.9 \%$. We can say that source of this increase were an average $14.2 \%$ increase in the technical efficiency change index and a $0.7 \%$ increase in the technological change index. For the same period, the biggest total factor productivity decrease was observed in 2006-2007 with an annual average of $0.8 \%$. We can say that the sources of this decrease were an average 13.1\% increase in the technical efficiency change index and a $12.3 \%$ decrease in the technological change index. The sources of positive technical efficiency change, which had an annual average of $13.1 \%$ between 2006 and 2007, were the annual average of 19.1\% positive pure efficiency change and the annual average of $6 \%$ negative scale efficiency change.

Table 3 shows the total factor productivity changes and their causes for 2003 to 2014.

Table 3. Changes in All Banks' Total Factor Productivity and Its Components, 2003-2014

(Malmquist Index Summary of Firms Means)

\begin{tabular}{|c|c|c|c|c|c|c|c|c|c|c|c|}
\hline Banks & TEC & TC & PTEC & SEC & TFPC & Banks & TEC & TC & PTEC & SEC & TFPC \\
\hline B-1 & 0.893 & 1.352 & 1.158 & 0.771 & 1.207 & B-22 & 0.987 & 1.065 & 0.987 & 1.000 & 1.051 \\
\hline B-2 & 1.051 & 0.865 & 0.998 & 1.053 & 0.909 & B-23 & 0.995 & 1.263 & 0.995 & 1.000 & 1.257 \\
\hline B-3 & 1.026 & 1.068 & 1.012 & 1.013 & 1.096 & B-24 & 0.987 & 1.212 & 0.987 & 1.000 & 1.197 \\
\hline B-4 & 1.056 & 0.929 & 1.056 & 1.000 & 0.982 & B-25 & 1.054 & 1.212 & 0.991 & 1.064 & 1.278 \\
\hline B-5 & 1.050 & 0.967 & 1.049 & 1.000 & 1.015 & B-26 & 0.999 & 1.096 & 0.999 & 1.000 & 1.095 \\
\hline B-6 & 0.844 & 1.004 & 0.979 & 0.869 & 0.848 & B-27 & 1.027 & 1.186 & 1.027 & 1.000 & 1.218 \\
\hline B-7 & 0.892 & 1.076 & 0.978 & 0.912 & 0.959 & B-28 & 1.063 & 1.024 & 1.008 & 1.055 & 1.089 \\
\hline B-8 & 0.982 & 1.013 & 0.986 & 0.996 & 0.995 & B-29 & 1.034 & 1.048 & 1.016 & 1.018 & 1.084 \\
\hline B-9 & 1.122 & 1.036 & 1.017 & 1.103 & 1.162 & B-30 & 1.009 & 1.052 & 1.009 & 1.000 & 1.061 \\
\hline B-10 & 1.076 & 0.995 & 1.073 & 1.003 & 1.072 & B-31 & 1.186 & 1.208 & 1.015 & 1.168 & 1.394 \\
\hline B-11 & 0.953 & 0.970 & 0.955 & 0.998 & 0.924 & B-32 & 1.005 & 1.116 & 0.982 & 1.023 & 1.121 \\
\hline B-12 & 1.045 & 0.924 & 1.063 & 0.983 & 0.965 & B-33 & 1.035 & 0.983 & 1.009 & 1.025 & 1.017 \\
\hline B-13 & 1.002 & 0.974 & 1.008 & 0.993 & 0.975 & B-34 & 1.000 & 0.953 & 1.000 & 1.000 & 0.953 \\
\hline
\end{tabular}




\begin{tabular}{|c|l|l|l|l|l|l|l|l|l|l|l|}
\hline B-14 & 1.036 & 1.329 & 1.037 & 0.999 & 1.377 & B-35 & 1.136 & 0.917 & 1.009 & 1.126 & 1.042 \\
\hline B-15 & 1.236 & 1.040 & 1.037 & 1.192 & 1.285 & B-36 & 1.047 & 0.883 & 1.001 & 1.046 & 0.925 \\
\hline B-16 & 1.017 & 0.919 & 1.026 & 0.992 & 0.935 & B-37 & 1.139 & 0.923 & 1.007 & 1.131 & 1.051 \\
\hline B-17 & 1.009 & 1.179 & 1.000 & 1.009 & 1.189 & B-38 & 1.064 & 0.898 & 1.000 & 1.064 & 0.955 \\
\hline B-18 & 1.023 & 1.177 & 1.030 & 0.993 & 1.204 & B-39 & 1.000 & 1.029 & 1.000 & 1.000 & 1.029 \\
\hline B-19 & 0.993 & 0.941 & 0.993 & 1.000 & 0.934 & B-40 & 0.973 & 0.905 & 1.000 & 0.973 & 0.881 \\
\hline B-20 & 1.022 & 0.959 & 1.026 & 0.996 & 0.980 & B-41 & 1.065 & 0.898 & 0.999 & 1.066 & 0.956 \\
\hline B-21 & 0.974 & 0.927 & 0.974 & 1.001 & 0.904 & B-42 & 1.035 & 0.910 & 1.000 & 1.035 & 0.943 \\
\hline Mean & 1.025 & 1.027 & 1.011 & 1.014 & 1.052 & Mean & 1.025 & 1.027 & 1.011 & 1.014 & 1.052 \\
\hline
\end{tabular}

Note: TEC; Technical Efficiency Change, TC; Technological Change; PTEC; Pure Technical Efficiency Change, SEC; Scale Efficiency Change and TFPC; Total Factor Productivity Change.

Table 3 shows that there was total factor productivity increase in 24 banks between 2003 and 2014, whereas there was a total factor productivity decrease in the remaining 18 banks. The largest total factor productivity decrease was observed in Arab Turkish Bank Inc. with an annual average of $15.2 \%$. The causes of this decrease are the $15.6 \%$ decrease in the technical efficiency change index and the $0.4 \%$ increase in the technological change index. On the other hand, sources of the 15.2\% annual average negative technical efficiency change of Arab Turkish Bank Inc. in the period between 2003 and 2014 are an annual average of $2.1 \%$ negative pure efficiency change and an annual average of $13.1 \%$ negative pure efficiency change. This means that Arab Turkish Bank Inc. could not use its production factors well and did not perform at the optimal production level. In the same period, the biggest total factor productivity increase was observed with Turkish Bank Inc. by annual average of $39.4 \%$. The sources of this increase are average of $18.6 \%$ increase in technical efficiency change and $20.8 \%$ increase in technological change index.

Table 4 presents the total factor productivity changes of the public-capital banks, the Joint Funds Bank Inc which was transferred to the Savings Deposit Insurance Fund of Turkey, the foreign-capital banks and the development and investment banks between 2003 and 2014.

Table 4. Changes in All Banks' Total Factor Productivity Change by 2003-2014 Periods

(Malmquist Index Summary)

\begin{tabular}{|c|c|c|c|c|c|c|c|c|c|c|c|}
\hline Banks & $\begin{array}{l}03 \\
04\end{array}$ & $\begin{array}{l}04 \\
05\end{array}$ & $\begin{array}{l}05 \\
06\end{array}$ & $\begin{array}{l}06 \\
07\end{array}$ & $\begin{array}{l}07 \\
08\end{array}$ & $\begin{array}{l}08 \\
09\end{array}$ & $\begin{array}{l}09 \\
10\end{array}$ & $\begin{array}{l}10 \\
11\end{array}$ & $\begin{array}{l}11 \\
12\end{array}$ & $\begin{array}{l}12 \\
13\end{array}$ & $\begin{array}{l}13 \\
14\end{array}$ \\
\hline-1 & .105 & 129 & 0.999 & 997 & 371 & 0.980 & 1.000 & 1.000 & 1.020 & 1.000 & 0.980 \\
\hline & & & & 98 & & & 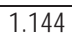 & & & & , \\
\hline & & 26 & 991 & 778 & 078 & 0 & .034 & 381 & 032 & & .90 \\
\hline & 76 & 202 & 141 & 053 & 325 & 1.186 & 1.015 & 883 & .975 & .95 & 1.197 \\
\hline & & 231 & 1.088 & 169 & .575 & 1.097 & 1.063 & 0.958 & .028 & .015 & 0.979 \\
\hline & & 125 & 185 & 260 & .023 & 0.866 & 1.221 & 0.715 & 911 & 1.617 & 0.054 \\
\hline & & & & & 52 & & 1.229 & 276 & & & .844 \\
\hline & & .994 & & 60 & 318 & 1.21 & 994 & 014 & 927 & .0 & .981 \\
\hline & & 1.001 & 000 & 009 & 997 & 1.00 & 002 & 994 & 002 & 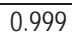 & .878 \\
\hline & 10 & 1.087 & 226 & 619 & .774 & 1.044 & 1.192 & 1.211 & 383 & .028 & 1.108 \\
\hline & 006 & 1.056 & 0.649 & 1.605 & 0.537 & 0.951 & 0.884 & 1.027 & 1.089 & 0.757 & 1.105 \\
\hline & & 1.243 & 1.219 & 1.175 & 0.331 & 1.007 & 0.999 & 0.934 & 1.024 & .019 & 0.954 \\
\hline & & & & & .764 & 0.9 & No & 1.111 & 1.163 & 04 & 0.972 \\
\hline & & 0.980 & & .042 & 654 & 1.9 & .96 & 1.060 & 0.858 & .943 & 1.043 \\
\hline & & 1.630 & 1.15 & .016 & 282 & 92 & .04 & .205 & .980 & .933 & 0.990 \\
\hline & & & & & 326 & 0 & 1.09 & 1.004 & L.022 & .966 & 1.032 \\
\hline & 132 & 0.783 & 1.123 & 0.840 & 6.093 & 1.162 & 1.064 & 1.049 & 1.018 & 0.984 & 1.016 \\
\hline & (008 & 1.001 & 0.903 & 0.802 & 9.020 & 0.964 & 1.073 & 1.057 & 1.068 & .907 & 1.103 \\
\hline & & 0.9 & & & 3 & 0.9 & & 1.051 & 1.063 & 866 & 1.085 \\
\hline & & & & & & & 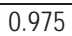 & 36 & 1.028 & 977 & 1.006 \\
\hline & & 1.1 & & 50 & (2) & 1.000 & 918 & 0.997 & 1.039 & .092 & 0.912 \\
\hline & & & & & & 1. & 0 & 39 & 0.947 & 000 & 1.000 \\
\hline & 995 & 1.059 & 93 & 1.054 & 5.950 & 1.008 & 0.864 & 0.818 & 1.273 & 1.014 & 0.994 \\
\hline B-2 & 1.373 & 1.021 & 0.354 & 0.407 & 9.549 & 0.979 & 0.960 & 0.906 & 0.867 & 1.212 & 1.011 \\
\hline B-2 & 1.157 & 0.766 & 1.662 & 1.001 & 9.313 & 0.878 & 0.971 & 1.154 & 0.885 & 1.271 & 0.977 \\
\hline
\end{tabular}




\begin{tabular}{|l|l|l|l|l|l|l|l|l|l|l|l|}
\hline B-26 & 0.787 & 0.958 & 0.887 & 1.018 & 1.232 & 1.735 & 1.193 & 0.830 & 1.538 & 0.125 & 9.735 \\
\hline B-27 & 1.081 & 0.798 & 1.256 & 0.993 & 8.463 & 1.055 & 0.984 & 0.937 & 1.051 & 0.965 & 0.980 \\
\hline B-28 & 1.434 & 0.866 & 1.371 & 1.190 & 1.090 & 0.918 & 1.125 & 0.959 & 1.162 & 1.050 & 0.958 \\
\hline B-29 & 1.239 & 1.133 & 0.983 & 1.179 & 1.056 & 1.359 & 0.984 & 0.987 & 1.008 & 1.013 & 1.045 \\
\hline B-30 & 0.996 & 0.906 & 1.029 & 0.440 & 1.152 & 1.031 & 1.718 & 1.023 & 0.999 & 2.244 & 1.006 \\
\hline B-31 & 1.391 & 1.760 & 1.004 & 0.876 & 6.975 & 0.915 & 1.770 & 0.730 & 1.411 & 1.150 & 1.342 \\
\hline B-32 & 0.878 & 1.243 & 1.046 & 1.120 & 2.422 & 1.076 & 1.053 & 1.004 & 1.020 & 0.966 & 1.019 \\
\hline B-33 & 1.083 & 1.218 & 1.103 & 0.973 & 0.679 & 1.034 & 1.035 & 1.090 & 1.013 & 1.047 & 1.009 \\
\hline B-34 & 0.981 & 1.042 & 1.007 & 0.956 & 0.212 & 0.864 & 1.071 & 1.554 & 1.308 & 1.927 & 0.784 \\
\hline B-35 & 1.360 & 1.288 & 1.171 & 1.105 & 0.349 & 0.999 & 1.307 & 1.172 & 0.987 & 1.226 & 1.072 \\
\hline B-36 & 1.303 & 1.162 & 1.171 & 1.013 & 0.208 & 0.846 & 1.120 & 1.105 & 1.009 & 1.056 & 1.017 \\
\hline B-37 & 1.297 & 1.362 & 1.472 & 1.331 & 0.375 & 1.058 & 1.144 & 1.025 & 0.990 & 1.004 & 1.081 \\
\hline B-38 & 1.171 & 1.007 & 1.217 & 1.069 & 0.281 & 0.882 & 1.160 & 1.175 & 1.079 & 1.058 & 1.021 \\
\hline B-39 & 0.966 & 0.949 & 0.960 & 0.684 & 1.318 & 1.519 & 1.058 & 1.038 & 1.052 & 0.993 & 0.990 \\
\hline B-40 & 1.063 & 0.618 & 0.939 & 0.966 & 0.338 & 0.940 & 1.109 & 1.134 & 0.996 & 1.062 & 0.985 \\
\hline B-41 & 1.210 & 1.103 & 1.325 & 1.136 & 0.262 & 0.927 & 1.133 & 1.068 & 1.016 & 0.987 & 1.033 \\
\hline B-42 & 1.070 & 1.160 & 0.972 & 1.230 & 0.310 & 0.966 & 1.062 & 1.020 & 0.993 & 1.048 & 1.045 \\
\hline
\end{tabular}

Table 5 presents the changes in the technical efficiencies of the public-capital banks, the Joint Funds Bank Inc which was transferred to the Savings Deposit Insurance Fund of Turkey, the foreign-capital banks and the development and investment banks between 2003 and 2014.

Table 5. Changes in All Banks' Technical Efficiency Change by 2003-2014 Periods

(Malmquist Index Summary)

\begin{tabular}{|c|c|c|c|c|c|c|c|c|c|c|c|}
\hline Banks & $\begin{array}{l}03 \\
04\end{array}$ & $\begin{array}{l}04 \\
05\end{array}$ & $\begin{array}{l}05 \\
06\end{array}$ & $\begin{array}{l}06 \\
07\end{array}$ & $\begin{array}{l}07 \\
08\end{array}$ & $\begin{array}{l}08 \\
09\end{array}$ & $\begin{array}{l}09 \\
10\end{array}$ & $\begin{array}{l}10 \\
11\end{array}$ & $\begin{array}{l}11 \\
12\end{array}$ & $\begin{array}{l}12 \\
13\end{array}$ & $\begin{array}{l}13 \\
14\end{array}$ \\
\hline B-1 & 0.101 & 2.080 & 1.023 & 1.401 & 0.914 & 0.884 & 1.031 & 1.136 & 0.925 & 1.074 & 1.021 \\
\hline B-2 & 1.266 & 1.068 & 1.182 & 1.148 & 0.926 & 0.740 & 1.169 & 0.992 & 1.123 & 1.039 & 1.014 \\
\hline B-3 & 1.379 & 1.057 & 1.042 & 1.090 & 0.693 & 0.997 & 1.052 & 1.198 & 1.027 & 0.997 & 0.895 \\
\hline B-4 & 1.490 & 1.127 & 1.151 & 1.100 & 0.858 & 1.063 & 1.059 & 0.797 & 1.004 & 0.930 & 1.196 \\
\hline B-5 & 1.165 & 1.155 & 1.097 & 1.221 & 0.966 & 0.983 & 1.109 & 0.865 & 1.053 & 1.005 & 0.980 \\
\hline B-6 & 1.578 & 1.056 & 1.237 & 1.282 & 1.112 & 0.853 & 1.242 & 0.621 & 0.904 & 1.526 & 0.058 \\
\hline B-7 & 2.288 & 0.880 & 1.059 & 0.894 & 1.164 & 0.943 & 1.206 & 0.241 & 0.548 & 0.996 & 0.853 \\
\hline B-8 & 0.707 & 0.934 & 1.168 & 1.307 & 0.958 & 1.224 & 0.951 & 0.868 & 0.900 & 0.965 & 0.965 \\
\hline B-9 & 2.959 & 1.021 & 1.000 & 1.444 & 1.008 & 0.781 & 1.049 & 1.079 & 1.005 & 1.020 & 0.890 \\
\hline B-10 & 1.417 & 1.020 & 1.249 & 0.644 & 0.952 & 0.935 & 1.243 & 1.094 & 1.417 & 1.017 & 1.108 \\
\hline B-11 & 0.914 & 0.990 & 0.655 & 1.680 & 0.963 & 0.879 & 0.900 & 0.886 & 1.117 & 0.719 & 1.089 \\
\hline B-12 & 1.242 & 1.166 & 1.229 & 1.227 & 0.925 & 0.902 & 1.042 & 0.843 & 1.049 & 1.009 & 0.956 \\
\hline B-13 & 0.889 & 1.178 & 0.753 & 1.545 & 0.983 & 0.658 & 1.000 & 1.073 & 1.126 & 1.095 & 0.977 \\
\hline B-14 & 0.999 & 0.995 & 1.006 & 1.801 & 0.609 & 1.641 & 0.986 & 1.014 & 0.823 & 0.960 & 1.037 \\
\hline B-15 & 5.337 & 1.531 & 1.182 & 1.052 & 1.135 & 0.821 & 1.091 & 1.078 & 1.015 & 0.916 & 0.992 \\
\hline B-16 & 1.322 & 0.965 & 1.018 & 1.135 & 0.964 & 0.797 & 1.138 & 0.907 & 1.047 & 0.956 & 1.034 \\
\hline B-17 & 1.101 & 0.736 & 1.358 & 1.000 & 1.000 & 1.000 & 1.000 & 1.000 & 1.000 & 1.000 & 1.000 \\
\hline B-18 & 1.011 & 1.008 & 1.008 & 1.349 & 0.801 & 0.907 & 1.076 & 1.161 & 0.978 & 0.955 & 1.091 \\
\hline B-19 & 1.314 & 0.917 & 1.134 & 0.992 & 0.925 & 0.856 & 0.900 & 0.949 & 1.089 & 0.856 & 1.086 \\
\hline B-20 & 1.180 & 1.007 & 1.028 & 1.144 & 0.959 & 0.967 & 1.017 & 0.936 & 1.053 & 0.967 & 1.008 \\
\hline B-21 & 1.010 & 1.000 & 0.941 & 1.011 & 1.004 & 1.046 & 0.910 & 0.870 & 1.022 & 1.024 & 0.899 \\
\hline B-22 & 1.009 & 0.994 & 0.990 & 1.257 & 1.000 & 0.692 & 1.019 & 1.033 & 0.950 & 1.000 & 1.000 \\
\hline B-23 & 0.724 & 1.152 & 1.155 & 1.188 & 0.854 & 0.953 & 0.886 & 0.877 & 1.278 & 1.024 & 0.997 \\
\hline B-24 & 1.000 & 1.000 & 1.000 & 0.928 & 0.958 & 0.951 & 0.975 & 0.961 & 0.870 & 1.246 & 1.014 \\
\hline B-25 & 1.069 & 0.722 & 2.224 & 1.198 & 1.000 & 0.727 & 0.944 & 1.205 & 0.840 & 1.274 & 0.982 \\
\hline B-26 & 0.824 & 1.046 & 0.960 & 1.303 & 0.374 & 1.335 & 1.244 & 0.750 & 1.575 & 0.129 & 9.698 \\
\hline B-27 & 1.141 & 0.834 & 1.348 & 1.047 & 1.000 & 1.000 & 1.000 & 1.000 & 1.000 & 1.000 & 1.000 \\
\hline B-28 & 1.445 & 0.812 & 1.391 & 1.241 & 0.978 & 0.822 & 1.174 & 0.866 & 1.191 & 1.039 & 0.959 \\
\hline B-29 & 1.246 & 1.063 & 0.999 & 1.226 & 0.746 & 1.202 & 1.027 & 0.891 & 1.033 & 1.002 & 1.048 \\
\hline B-30 & 1.052 & 0.951 & 1.081 & 0.525 & 0.517 & 0.959 & 1590 & 1.072 & 0.962 & 2.323 & 1.031 \\
\hline
\end{tabular}




\begin{tabular}{|c|c|c|c|c|c|c|c|c|c|c|c|}
\hline B-31 & 1.353 & 1.657 & 1.205 & 0.911 & 1.411 & 0.694 & 1.847 & 0.659 & 1.446 & 1.139 & 1.350 \\
\hline B-32 & 0.865 & 1.168 & 1.127 & 1.102 & 0.913 & 0.914 & 1.099 & 0.907 & 1.045 & 0.947 & 1.019 \\
\hline B-33 & 1.092 & 1.143 & 1.112 & 1.016 & 0.965 & 0.927 & 1.080 & 0.985 & 1.037 & 1.036 & 1.011 \\
\hline B-34 & 1.000 & 1.000 & 1.000 & 1.000 & 1.000 & 1.000 & 1.000 & 1.000 & 1.000 & 1.000 & 1.000 \\
\hline B-35 & 1.374 & 1.208 & 1.181 & 1.154 & 1.076 & 0.896 & 1.349 & 1.052 & 1.011 & 1.208 & 1.073 \\
\hline B-36 & 1.316 & 1.090 & 1.181 & 1.063 & 0.986 & 0.798 & 1.141 & 0.953 & 1.047 & 1.018 & 1.011 \\
\hline B-37 & 1.309 & 1.277 & 1.484 & 1.391 & 1.092 & 0.948 & 1.184 & 0.917 & 1.023 & 0.977 & 1.078 \\
\hline B-38 & 1.182 & 0.945 & 1.228 & 1.117 & 1.119 & 0.798 & 1.187 & 1.035 & 1.123 & 1.028 & 1.018 \\
\hline B-39 & 1.000 & 1.000 & 1.000 & 0.918 & 0.861 & 1.265 & 1.000 & 1.000 & 1.000 & 1.000 & 1.000 \\
\hline B-40 & 1.000 & 0.669 & 0.986 & 1.034 & 1.073 & 1.213 & 0.961 & 0.941 & 0.965 & 0.988 & 0.969 \\
\hline B-41 & 1.222 & 1.035 & 1.337 & 1.192 & 1.022 & 0.852 & 1.157 & 0.942 & 1.056 & 0.960 & 1.031 \\
\hline B-42 & 1.080 & 1.088 & 0.980 & 1.285 & 1.042 & 0.866 & 1.104 & 0.912 & 1.026 & 1.020 & 1.042 \\
\hline
\end{tabular}

Table 6 presents the technological change indices of the public-capital banks, the Joint Funds Bank Inc which was transferred to the Savings Deposit Insurance Fund of Turkey, the foreign-capital banks and the development and investment banks between 2003 and 2014.

Table 6. Changes in All Banks' Technological Efficiency Change by 2003-2014 Periods

(Malmquist Index Summary)

\begin{tabular}{|c|c|c|c|c|c|c|c|c|c|c|c|}
\hline Banks & 04 & $\begin{array}{l}04 \\
05\end{array}$ & $\begin{array}{l}05 \\
06\end{array}$ & $\begin{array}{l}06 \\
07\end{array}$ & $\begin{array}{l}07 \\
08\end{array}$ & $\begin{array}{l}08 \\
09\end{array}$ & $\begin{array}{l}09 \\
10\end{array}$ & $\begin{array}{l}10 \\
11\end{array}$ & $\begin{array}{l}11 \\
12\end{array}$ & $\begin{array}{l}12 \\
13\end{array}$ & $\begin{array}{l}13 \\
14\end{array}$ \\
\hline 1 & .040 & .024 & & 711 & .797 & 109 & & 0.880 & 1.103 & .932 & 0.961 \\
\hline 8 & & & & & & & & & & & \\
\hline B-3 & & & & & & & & & & & 014 \\
\hline B-4 & & 066 & & 57 & 379 & .11 & & $\overline{10}$ & 971 & & $\overline{00}$ \\
\hline & & 066 & 2 & 957 & 595 & 1.116 & 958 & 107 & 976 & 01 & 998 \\
\hline B- & & (2) & & 983 & 921 & 1.016 & & & 007 & 0 & .927 \\
\hline B-7 & & & & & 76 & 108 & & & 012 & 003 & .989 \\
\hline & & & & & & 1996 & & & & .073 & .016 \\
\hline & & & & 8 & 31 & 1.28 & & $9 \angle 1$ & 998 & .919 & 986 \\
\hline$B-1$ & & & & & 813 & 1.11 & ת & 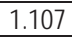 & 910 & & .000 \\
\hline B- & 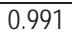 & 1.066 & 992 & 955 & .558 & 1.082 & 0.982 & 1.159 & .974 & .054 & .015 \\
\hline & & 1.066 & 992 & 957 & 358 & 1.116 & 0.958 & 1.107 & 0.976 & .010 & 0.998 \\
\hline & & & & 746 & 777 & 1.382 & & & 1.032 & 1.009 & 0.995 \\
\hline & & & & & & & & & & & .005 \\
\hline & & & & & & & & & 966 & 18 & 998 \\
\hline & & & & & & 1 & & 10 & 976 & .010 & 998 \\
\hline & & & 21 & 340 & 093 & 1.162 & .068 & $04 \mathrm{C}$ & .018 & .984 & .016 \\
\hline & & 993 & 6 & 594 & 258 & 1.062 & 0.997 & 0.911 & 1.092 & 0.949 & .011 \\
\hline & & & & 957 & 436 & 1.116 & 0.958 & 1.107 & .976 & 12 & 998 \\
\hline & & & & & & & & & & & 998 \\
\hline & & & & & $\leq$ & 09 & & 147 & 16 & & .015 \\
\hline & & & & 742 & 594 & 1.44 & 0.980 & 90 & 996 & .000 & .000 \\
\hline & & & & & & & & & 996 & 90 & .996 \\
\hline B- & & $0 \angle 1$ & & 438 & 4.284 & 1.030 & 0.985 & 43 & 0.996 & .973 & 0.997 \\
\hline & & & & 6 & 9.313 & 1.207 & 1.029 & 0.957 & 1.053 & .998 & .995 \\
\hline & & & & & & & & & 0.976 & 75 & .004 \\
\hline & & & & & 2 & 4 & & 37 & 51 & 65 & 980 \\
\hline & & & & & I & 11 & 0958 & 11 & .976 & 10 & .998 \\
\hline & & & & & 4 & \pm & 0 & 07 & 0.976 & 010 & .997 \\
\hline & 47 & 952 & 952 & 837 & 2.230 & 1.075 & .081 & 0.954 & 1.038 & .966 & .976 \\
\hline B-3 & 28 & 1.062 & 333 & 0.962 & 4.942 & 1.317 & 0.958 & 1.107 & .976 & .010 & .993 \\
\hline & & & & & 3 & 1.1 & 0. & 1.101 & 0.976 & 20 & .000 \\
\hline & & & & & & & & & 10 & & .998 \\
\hline & & & & & .4 & 0.00 & 1.011 & 1.554 & 1.308 & .927 & .784 \\
\hline 87 & 0.990 & 1.066 & 0.992 & 0.9 & 0.0 & 1.1 & 0.96 & 1.11 & 0.976 & 1.015 & 0.999 \\
\hline
\end{tabular}




\begin{tabular}{|l|l|l|l|l|l|l|l|l|l|l|l|}
\hline B-36 & 0.990 & 1.066 & 0.992 & 0.954 & 0.210 & 1.060 & 0.981 & 1.159 & 0.964 & 1.037 & 1.006 \\
\hline B-37 & 0.990 & 1.066 & 0.992 & 0.957 & 0.343 & 1.116 & 0.966 & 1.117 & 0.968 & 1.027 & 1.003 \\
\hline B-38 & 0.990 & 1.066 & 0.992 & 0.957 & 0.251 & 1.106 & 0.977 & 1.136 & 0.961 & 1.029 & 1.003 \\
\hline B-39 & 0.966 & 0.949 & 0.960 & 0.745 & 1.530 & 1.200 & 1.058 & 1.038 & 1.052 & 0.993 & 0.990 \\
\hline B-40 & 1.063 & 0.924 & 0.953 & 0.934 & 0.315 & 0.775 & 1.154 & 1.204 & 1.032 & 1.075 & 1.016 \\
\hline B-41 & 0.990 & 1.066 & 0.992 & 0.953 & 0.257 & 1.088 & 0.979 & 1.134 & 0.962 & 1.029 & 1.003 \\
\hline B-42 & 0.990 & 1.066 & 0.992 & 0.957 & 0.297 & 1.116 & 0.962 & 1.118 & 0.967 & 1.027 & 1.003 \\
\hline
\end{tabular}

\section{Conclusion}

Banks' doing business in productive or unproductive ways, changes in productivity over time, and sources of these changes are of interest not only to the banks in question, but also to other sectors, customers, countries, policy makers and researchers. Knowing if and why these banks are productive and using this knowledge to increase their productivity through new strategies will increase banks' productivity and competitiveness and positively affect the sectors with which they interact.

In our study, which analyzed the total factor productivity of 42 banks that were actively operating in Turkey's banking sector between 2003 and 2014, we conducted a detailed analysis of total factor productivities and their components of the banks using the output-oriented Malmquist Total Factor Productivity Index under the assumption of constant returns with respect to scale.

We determined that there was on average a $5.2 \%$ increase in the total factor productivity of banks from 2003 to 2014. The sources of this increase were a $2.5 \%$ average increase in the technical efficiency change index and a $2.7 \%$ increase in the technological change index. In other words, banks managed their existing production factors well and operated at the optimal production scale. In the same period, we found an increase in the total factor productivity in all years except for 2006-2007, 2010-2011 and 2013-2014.

It can be said that 18 of the 42 banks in our study were unproductive, while the remaining 24 banks were productive. Of the 3 public-capital banks, Turkish Vakif Bank Corporation was unproductive between 2003 and 2014. Of the 11 private-capital banks, Akbank Inc., Turkish Garanti Bank Inc. Turkish Is Bank Inc. and Yapi Kredi Bank Inc were unproductive. Of the 15 foreign-capital banks, Alternatifbank, Arab Turkish Bank Inc., Bank Mellat, Citibank Inc., Denizbank Inc., Deutsche Bank Inc., Finans Bank Inc., HSBC Bank Inc., ING Bank were unproductive. Of 12 development and investment banks, BankPozitif Credit and Development Bank Inc., Ilbank, Turk Eximbank and Turkish Industrial and Development Bank Inc. were unproductive between 2003 and 2014.

The results of this study are limited to the data received from the banks for the analysis period, the input and output variables used and its method of analysis. Using a different period, other variables and methods may lead to different results.

\section{References}

Ada, A. A., Dalkilıç, N. (2014). Efficiency Analysis in Islamic Banks: A Study for Malaysia and Turkey, Journal of BRSA Banking and Financial Markets, 8 (1), 9-33.

Akyüz, Y., Yıldız, F., Kaya, Z. (2013). Measuring Total Factor Productivity with The Malmquist Index and Data Envelopment Analysis (DEA): An Application in Deposit Banks Listed in BIST, Ataturk University Journal of Economics and Administrative Sciences, 27 (4), 110-130. (in Turkish).

Alam, I. M. S. (2001). A Nonparametric Approach for Assessing Productivity Dynamics of Large U.S. Banks, Journal of Money, Credit and Banking, 33 (1), 121-139.

Angelidis, D., Lyroudi, K. (2006). Efficiency in the Italian Banking Industry: Data Envelopment Analysis and Neural Networks, International Research Journal of Finance and Economics, 5, 155-165.

Arjomandi, A., Valadkhani, A., Harvie, C. (2011). Analysing Productivity Changes Using the Bootstrapped Malmquist Approach: The Case of the Iranian Banking Industry, Australasian Accounting, Business and Finance Journal, 5 (1), 35-56.

Arnade, C. (1994), Using Data Envelopment Analysis to Measure International Agricultural Efficiency and Productivity, United States Department of Agriculture Technical Bulletin, Number: 1831, Economic Research Service, Washington.

Asmild, M., Paradi, J.C., Aggarwall, V. and Schaffnit, C. (2004). Combining DEA Window Analysis with the Malmquist Index Approach in a Study of the Canadian Banking Industry, Journal of Productivity Analysis, 21, 67-89.

Aysan, A. A., Ceyhan, Ş. P. (2007). Market Disciplining Role of Crisis on The Restructuring of the Turkish Banking Sector, ISS/EC-200718, Research Papers, www.econ.boun.edu.tr/public_html/RePEc/pdf/200718.pdf.

Bastı, E. (2005). The Effects on Turkey Commercial Banking Sector's Total Factor Productivity of 2001 Financial Crisis, Journal of Economics Business and Finance, Private Issue, $63-79$ (in Turkish). 
Boussofiane, A., Dyson, R., Rhodes, E. (1991), "Applied Data Envelopment Analysis", European Journal of Operational Research, II(6), 1-15.

Boyacıoğlu, M. A., Şahin, I. E., Aktaş, R. (2014). A Comparison of The Financial Efficiencies of Commercial Banks and Participation Banks: The Case of Turkey, 11th International Academic Conference, Reykjavik, http:proceedings.iises.net/index.php?action= proceedings IndexConference\&id $=3$.

Bozdağ, E. G., Altan, M. S., Bozdağ, A. E. (2010). Bankacılık Sisteminde Etkinlik ve Verimlilik (Veri Zarflama Analizi ile Bir Uygulama), Aksaray Üniversitesi iliBF Dergisi, Cilt: 2, Sayl: 1, 33-47. (in Turkish).

Büyükkılıç, D., Yavuz, İ. (2005), Imalat Sanayinde Toplam Faktör Verimliliği: Teknik Değişim, Teknik Etkinlik (1994-2001), MPM Yayınları No: 685, Ankara: MPM Yayınları.

Casu, B., Girardone, C., Molyneux, P. (2004). Productivity Change in Banking: A Comparison of Parametric and Non-Parametric Approaches, Journal of Banking and Finance, Vol. 28, No. 10, 2521-2540.

Caves, R. E., Christensen, L., Diewert, W. E. (1982), "The Economic Theory Index Number and The Measurement of Output and Productivity", Econometrica, 50 (6), 1393-1414.

Chambers, N., Çifter, A. (2006). The Effect of Scale on Productivity of Turkish Banks in the Post-Crises Period: An Application of Data Envelopment Analysis, Traditional International Finance Symposium, Marmara University, http://mpra.ub.uni-muenchen.de/2487.

Cingi, S. and Tarım, A. (2000). Performance Measurement in Turkish Banking System: An Application of DEA-Malmquist TFP index. TBB Araşıtıma Tebliğleri Serisi, (1), 95-112 (in Turkish).

Çoban, O., Yorgancilar, F. N., Kabaklarlı, E. (2015). Testing The Effects of Brsa on Turkish Banking Sector By Malmquist Indeks (19952010), Niğde Üniversitesi İktisadi ve Idari Bilimler Fakültesi Dergisi, Cilt: 8, Sayı: 2, 121-141. (in Turkish).

Coelli, T. J. (1996), A Guide to DEAP Version 2.1: A Data Envelopment Analysis (Computer) Program, Working Paper No. 8, Centre for Efficiency and Productive Analysis Department of Econometrics University of New England, Armidale.

Coelli, T. J., Rao, D. S. P., O'Donnell, C. J., Battese, G. E. (2005), An Introduction to Efficiency and Productivity Analysis, Kluwer Publication, Boston.

Deliktaş, E. (2002). Eficiency and Analysis of Total Factor Productivity Growth in Private- Owned Manufacturing Industry in Turkey, METU Studies in Development, 29(3-4), 247-284.

Deliktaş, E. (2006), İzmir Küçük, Orta ve Büyük Ölçekli İmalat Sanayinde Üretim Etkinliği ve Toplam Faktör Verimliği Analizi, Working Papers in Economics, Working Paper No: 06/03, 1-45.

Dizkıııı, A. S., Gökgöz, A. (2015). Evaluating The Financial Performances of The Banks Listed on Istanbul Stock Exchange Banks Index by Data Envelopment Analysis and Malmquist Index, Journal of Accounting, Finance and Auditing Studies, 1(2), 61-77.

Drake, L. (2001). Efficiency and Productivity Change in UK Banking, Applied Financial Economics, 11, 557-571.

Eken, H. M., Kale, S. (2011). Measuring Bank Branch Performance Using Data Envelopment Analysis (DEA): The Case of Turkish Bank Branches, African Journal of Business Management, 5(3): 889-901.

Ekren, N., Emiral, F. (2002). Türk Bankacılık Sisteminde Etkinlik Analizi (Veri Zarflama Analizi Uygulaması), Active Bankaclık ve Finans Dergisi, Sayl: 24, 2002, 1-32.

Fare, R., Grosskopf, S., Norris, M., Zhang, Z. (1994), "Productivity Growth, Technical Progress and Efficiency Change in Industrialized Countries", American Economic Review, 84(1), 66-83.

Fukuyama, H. (1995). Measuring Efficiency and Productivity Growth in Japanese Banking: A Nonparametric Frontier Approach, Applied Financial Economics, 5, 95-107.

Galagedera, D. and Edirisuriya, P. (2004). Performance of Indian Commercial Banks (1995-2002): An Application of Data Envelopment Analysis and Malmquist Productivity Index, Finance 0408006, EconWPA.

Grifell-Tatje, E., Lovell, C.A.K. (1996). Deregulation and Productivity Decline: The Case of Spanish Savings Banks, European Economic Review, 40, 1281-1303.

Grosskopf, S. (1993), "The Measurement of Productive Efficiency: Techniques and Applications", Efficiency and Productivity, (Ed. H.O. Fried, C.A.K. Lovell, S.S. Schmidt), Oxford University Pres, New York.

Hadad, M. D., Hall, M. J. B., Kenjegalieva, K., Santoso, W., Satria, R. Simper, R. (2008), Efficiency and Malmquist Indices of Productivity Change in Indonesian Banking, Loughborough University. Department of Economics, Discussion Paper Series, https://dspace. Iboro.ac.uk/2134/4200.

Işık, l., Hassan, M. K. (2003). Financial Disruption and Bank Productivity: The 1994 Experience of Turkish Bank, The Quarterly Review of Economics and Finance, 43, 291-320.

Jackson, P. M., Fethi, M. D., İnal, G. (1998). Efficiency and Productivity Growth in Turkish Commercial Banking Sector: A non-parametric approach, European Symposium on: Data Envelopment Analysis-Recent Development and Applications, Wernigerode, Germany, 16-18 October.

Karacabey, A. A., Arslan, B. H. (2004). Analyzing the Production Changes or the Turkish Banking System, http://dx.doi.org/10.2139/ ssrn. 485582.

Kasman, S., Kasman, A. (2011). Efficiency, Productivity and Stock Performance: Evidence from the Turkish Banking Sector, Panoeconomicus, 58(3), 355-372.

Keskin Benli, Y., Değirmen, S. (2013). The Application of Data Envelopment Analysis Based Malmquist Total Factor Productivity Index: Empirical Evidence in Turkish Banking Sector, Panoeconomicus, 2, Special Issue, 139-159.

Kirikal, L., Sõrg, M., Vensel, V. (2004). Estonian Banking Sector Performance Analysis Using Malmquist Indexes And DuPont Financial Ratio Analysis, International Business \& Economics Research Journal, 3 (12), 21-36. 
Kök, D., Ay, O. E. (2013). A Research on The Reflection of 2008 Global Financial Crisis on The Efficiency Level of Turkish Banking Sector in The Period of 2007-2009, International Journal of Economic and Administrative Studies, 5 (10), 155-170. (in Turkish).

Kutlar, A., Kabasakal, A., Babacan, A. (2015). Dynamic Efficiency of Turkish Banks: A DEA Window and Malmquist Index Analysis for The Period of 2003-2012, Sosyoekonomi, 23 (24), 71-97.

Mahadevan, R. (2002). A DEA Approach to Understanding the Productivity Growth of Malaysia's Manufacturing Industries, Asia Pacific Journal of Management, 19, 587-600.

Malmquist, S. (1953). The Making of Index Numbers and Indifference Surfaces, Trabajos de Estadistica, 4 (2), $209-242$.

Muvingi, J., Hotera, S. (2015). Zimbabwe Commercials Banks Efficiency and Productivity Analysis Through DEA Malmquist Approach: 2002-2012, Journal of Data Envelopment Analysis and Decision Science, No. 1, 32-49.

Neupane, B. (2013). Efficiency and Productivity of Commercial Banks in Nepal: A Malmquist Index Approach, Asian Journal of Finance\&Accounting, Vol. 5, No. 2, 220-243.

Öncü, S., Aktaş, R. (2007). Productivity Changes in Turkish Banking Sector During The Restructuring Period, Celal Bayar University The Faculty of Economic and Administrative Sciences Journal of Management and Economics, 14 (1), 247-266. (in Turkish).

Perçin, S., Yakıcı Ayan, T. (2006). Measuring Efficiency of Commercial Banks in A Developing Economy: The Case of Turkey, Investment Management and Financial Innovations, Volume 3, Issue 2, 217-231.

Primorac, M., Troskot, Z. (2005). Measuring The Efficacy and Productiveness of Croatian Banks with The Malmquist Index of Change in Total Factor Productivity, Financial Theory and Practice, Vol. 29, No. 4, 309-325.

Rahman, A. A., Rosman, R. (2013). Efficiency of Islamic Banks: A Comparative Analysis of MENA and Asian Countries, Journal of Economic Cooperation and Development, 34, 1, 63-92.

Raphael, G.. (2013). A DEA- Based Malmquist Productivity Index Approach in Assessing Performance of Commercial Banks: Evidence From Tanzania, European Journal of Business and Management, 5 (6), 25-34.

Reda, M. (2008). Empirical Study on Efficiency and Productivity of the Banking Industry in Egypt, Proceedings of the African Economic Conference. (accessed on 2nd January 2008), 55-88, available at http://www.afdb.org/fileadmin/uploads/afdb/Documents/ Knowledge/30756891-EN-3.1.2-EFFICIENCY-AND-PRODUCTIVITY-OF-THE-BANKING-INDUSTRY-IN-EGYPT.PDF.

Rezitis A. (2006). Productivity Growth in the Greek Banking Industry: A Nonparametric Approach, Journal of Applied Economics, 9 (1), 119-138.

Sathye, M. (2002). Measuring Productivity Changes in Australian Banking: An Application of Malmquist Indices, Managerial Finance, Vol. 28, No. 9, 48-59.

Sharma, S., Gupta, S. (2010). Malmquist Productivity and Efficiency Analysis for Banking Industry in India, International Journal of Business Excellence, 3 (1), 65-76.

Shepard, R. W. (1970). The Theory of Cost and Production Functions, Princeton University Press, Princeton.

Sturm, J., Williams, B. (2004). Foreign Bank Entry, Deregulation and Bank Efficiency: Lessons from the Australian Experience, Journal of Banking and Finance, 28, 1775-1799.

Sufian, F. (2007). The Efficiency of Islamic Banking Industry in Malaysia: Foreign vs Domestic Banks, Humanomics: The International Journal of Systems and Ethics, Emerald Group Publishing, vol. 23(3), 174-192

Türker Kaya, Y., Doğan, E. (2005). Efficiency Change During The Disinflation Period in The Turkish Banking Sector, Ankara: Banking Regulation and Supervision Agency. (in Turkish).

Ünvan, Y. A., Tatlıdil, H. (2012). Efficiency in the Turkish Banking System: A Data Envelopment Approach, International Journal of Basic\&Applied Sciences, Vol: 12, No: 02, 168-186.

Vivas, A., Humphrey, D. B. (2002). Bias in Malmquist Index and Cost Function Productivity Measurement in Banking, International Journal of Production Economics, 76(2): 177-188.

Worthington, A.C. (1999). Malmquist Indices of Productivity Change in Australian Financial Services, Journal of International Financial Markets, Institutions and Money, 9, 303-320. 